\title{
Den hygieniska medborgaren Hälsoupplysningens kris i Finland i början av 1900-talet
}

Minna Harjula

\begin{abstract}
Inledning
"Alla ska vara med", skrev distriktsläkaren Konrad ReijoWaara år 1906 och syftade på den plan han hade i åtanke för att förbättra Finlands folkhälsa. ReijoWaara - grundare av och chefredaktör för Terveydenhoitolehti, den ledande finskspråkiga tidskriften för hälsoupplysning jämförde landets höga dödlighet med den i övriga nordiska länder och redogjorde också för de förtida dödsfallens betydelse för landets ekonomi. Han menade att den beklagliga situationen berodde på befolkningens bristfälliga förmåga att anamma renlighet som ideal och praktik. Enligt ReijoWaara var varje medborgares tillgång till hälsoupplysning en förutsättning för en sund nation. Som lösning på problemet lade han fram en ambitiös plan som syftade till att involvera alla medborgare i lokala verksamheter för utbyten av kunskaper om hur man lever ett hälsosamt liv. Verksamheten var tänkt att vara opolitisk och förväntades överskrida alla gränser som utgjordes av kön, klass och förmögenhet. ${ }^{1}$ Med stöd från den akademiska världen och statsförvaltningen kunde hans idé om en nationell satsning förverkligas: Finlands nationella hälsovårdsförbund (Kansallinen Terveysliitto) grundades år 1906. ${ }^{2}$

Att bedriva hälsoupplysning på frivillig grund via folkrörelser var inte ett särdrag för Finland, utan detta präglade samtliga nordiska länder. ${ }^{3}$ Medborgarverksamheten hade emellertid mycket stor betydelse för
\end{abstract}


folkhälsan i Finland. Detta berodde dels på den relativt sena tillkomsten av hälso- och sjukvårdstjänster i landet. I början av I900-talet hade Finland inget riksomfattande system för hälso- och sjukvård. År 1903 fanns det 7500 invånare på en läkare i Finland, vilket var påfallande många jämfört med siffrorna för Sverige (4 400) och Norge (2 ooo). Förutom cirka 50 statliga distriktsläkare baserades tillgången till hälsovårdstjänster huvudsakligen på lokala initiativ och på privata läkarmottagningar i städer i landets södra delar. ${ }^{4}$ Dels innebar avsaknaden av obligatorisk skolgång fram till I92 I - till skillnad från de övriga nordiska länderna som alla hade infört skolplikt senast vid sekelskiftet - att det var medborgarorganisationer, och inte skolor, som utgjorde den huvudsakliga arenan för hälsoupplysning i Finland. 5

Finlands nationella hälsovårdsförbund (FNH) fick emellertid inte det gensvar från allmänheten som ReijoWaara hade förväntat sig och förbundet avvecklades redan 1920. ${ }^{6}$ Vid den här tidpunkten befann sig hälsopolitiken i en brytningstid. Fokus låg nu på att säkerställa tillgången till offentliga hälso- och sjukvårdstjänster. FNH:s uppgång och fall gör det därmed möjligt att studera en central vändpunkt inom den finländska hälsopolitiken. Syftet med kapitlet är att analysera argumenten för och emot FNH som olika synsätt på hälsomedborgarskap i Finland. Jag använder begreppet "hälsomedborgarskap" som ett analytiskt verktyg för att undersöka det komplexa samspelet mellan hälsorelaterade rättigheter och skyldigheter för enskilda individer och samhället. Jag anser att relationen mellan individ och samhälle är det centrala i hälsopolitiken: uppfattningen om vem som bär huvudansvaret för individens hälsa och hur det definieras ligger till grund för hur hälso- och sjukvårdssystem organiseras. Förutom den formella, juridiska aspekten i förhållandet mellan individ och samhälle omfattar hälsomedborgarskapet även informella aspekter på tillhörighet och medlemskap. ${ }^{7}$

Jag utgår från erfarenhetshistoriska utgångspunkter, vilka framhåller att individen formar och tolkar sin sociala verklighet i interaktion med andra människor genom erfarenheter. Erfarenheterna blir lagrade, särskilt i språket, men också i institutionella praktiker. Erfarenheterna är temporalt flerlagrade: de är förknippade med det förflutna, nuet och framtiden. Jag konstaterar att det omstridda hälsomedborgarskapet 
baseras på olika erfarenheter som är förknippade med skiftande förväntningar, förhoppningar och farhågor om framtiden. Spänningen mellan erfarenheter och förväntningar kan ses som den styrande dynamiken bakom sociala reformer. ${ }^{8}$ I det här kapitlet argumenterar jag för att relationen mellan individ och samhälle, på vilken ReijoWaara baserade sin vision om medborgarskap och hälsa, inte längre hade någon relevans som ett löfte om en bättre framtid i den samhällsomvandling som Finland befann sig i vid början av I900-talet. Genom att erbjuda en alternativ vision för hälsomedborgarskap öppnade kritiken mot FNH upp för nya perspektiv på den nationella hälsopolitiken.

Begreppet "den hygieniska medborgaren" i rubriken hänvisar till den fundamentala roll som hygien och renlighet spelade i det tidiga I900-talets Finland. En livlig debatt kring hygien och hälsa började i samband med de snabba samhällsförändringarna som ledde till en bred omdefiniering av medborgerliga rättigheter. Utöver den allmänna rösträtten och riksdagsreformen I906, som ersatte ståndssystemet med moderna politiska partier, breddades också de medborgerliga rättigheterna till att omfatta yttrandefrihet och mötesfrihet - åtminstone i princip. Diskussionen om hälsa färgades också av landets politiska kontext, som kännetecknades av nationalism och strävan efter självständighet från Ryssland (1917), samt en politisk polarisering på randen till ett inbördeskrig (I9I8). ${ }^{\text {? }}$

\section{Vision - ett enat folk i den hygieniska väckelsen}

Inom hälsovården kan vi inte förvänta oss att uppnå goda resultat förrän vi alla arbetar tillsammans för folkets hälsoskydd, som gäller oss alla i samma utsträckning [...] Finlands folk måste utbildas i att förstå detta klart och tydligt. Finlands folk måste väckas till självkännedom och aktivitet också inom hälsovården. ${ }^{10}$

Initiativtagaren till FNH, ReijoWaara, såg det i början av I900-talet som sin högsta prioritet att göra folket medvetet om nationens hälsotillstånd. Han kritiserade därmed sina landsmän för deras bristande förståelse för betydelsen av fysisk och mental renlighet. ${ }^{11}$ Enligt ReijoWaara hade 
individen ett eget ansvar för sin hälsa som en plikt mot nationen: "Det rena livet är det första offret som vårt gemensamma Moder Finland kräver av oss under denna stora uppvaknandets tid." ${ }^{12}$ Visionen var att skapa exemplariskt rena boendemiljöer som också präglades av måttfullhet och sedlighet. ${ }^{13}$ Såsom Karolina Wiell visar i sitt kapitel sågs den finska bastutraditionen som en källa till nationell stolthet och som en tillgång i arbetet för att främja hygien. Enligt medicinska experter behövde finländarna emellertid handledning i att bygga och använda bastur på ett hälsosamt sätt så att inga smittsamma sjukdomar spreds vid användningen. ${ }^{14}$ Utöver ett bastubad per vecka förväntades folk införa dagliga renlighetsrutiner och förstå vikten av förebyggande åtgärder i bekämpningen av sjukdomar. ${ }^{15}$

Med sina studieresor i Skandinavien, Tyskland och Storbritannien och regelbunden publicering av texter översatta från andra nordiska hälsotidskrifter i Terveydenhoitolehti, var ReijoWaara en del av det nordiska expertnätverket inom hygien. ${ }^{16}$ I likhet med sina kollegor i övriga Norden lade ReijoWaara stor tonvikt på begreppet "folk" (kansa). Det finska språket utmärks av den nära kopplingen mellan termerna kansa ("folk") och kansalainen ("medborgare"). Detta samband betonar medlemskap och tillhörighet i samhället som viktiga förutsättningar för medborgarskap. Det finska begreppet kansa bar på en retorisk kraft, eftersom det inte bara syftade på nation och folk utan också på befolkning, lägre klasser - och ibland till och med på staten. ${ }^{17}$

Syftet med ReijoWaaras riksomfattande hälsoupplysningsplan var att väcka alla folklager. ${ }^{18}$ Förekomsten av olika folklager ansågs självklart i det finska ståndssamhället. Följaktligen tilldelade ReijoWaara folklagren olika roller i sin nationella hälsoplan. För de högre klasserna beskrevs upplysningsprogrammet som hygieniskt väckelsearbete och inre mission. ${ }^{19}$ Det var de välbeställdas uppgift att vägleda underklassen till insikt om hälsans betydelse. Allmogen förväntades vara ansvarsfulla medborgare och acceptera sin plats i samhället och att vägledas av medel- och överklassen. ${ }^{20}$

Bild 7.I. Konrad ReijoWaara vid 60 års ålder 1913. Vid den tidpunkten hade hans vision om att involvera alla medborgare i Finlands nationella hälsovårdsförbund börjat mattas av. Källa: Terveydenhoitolehti 3 1913/Digitala samlingar, Finlands nationalbibliotek. 


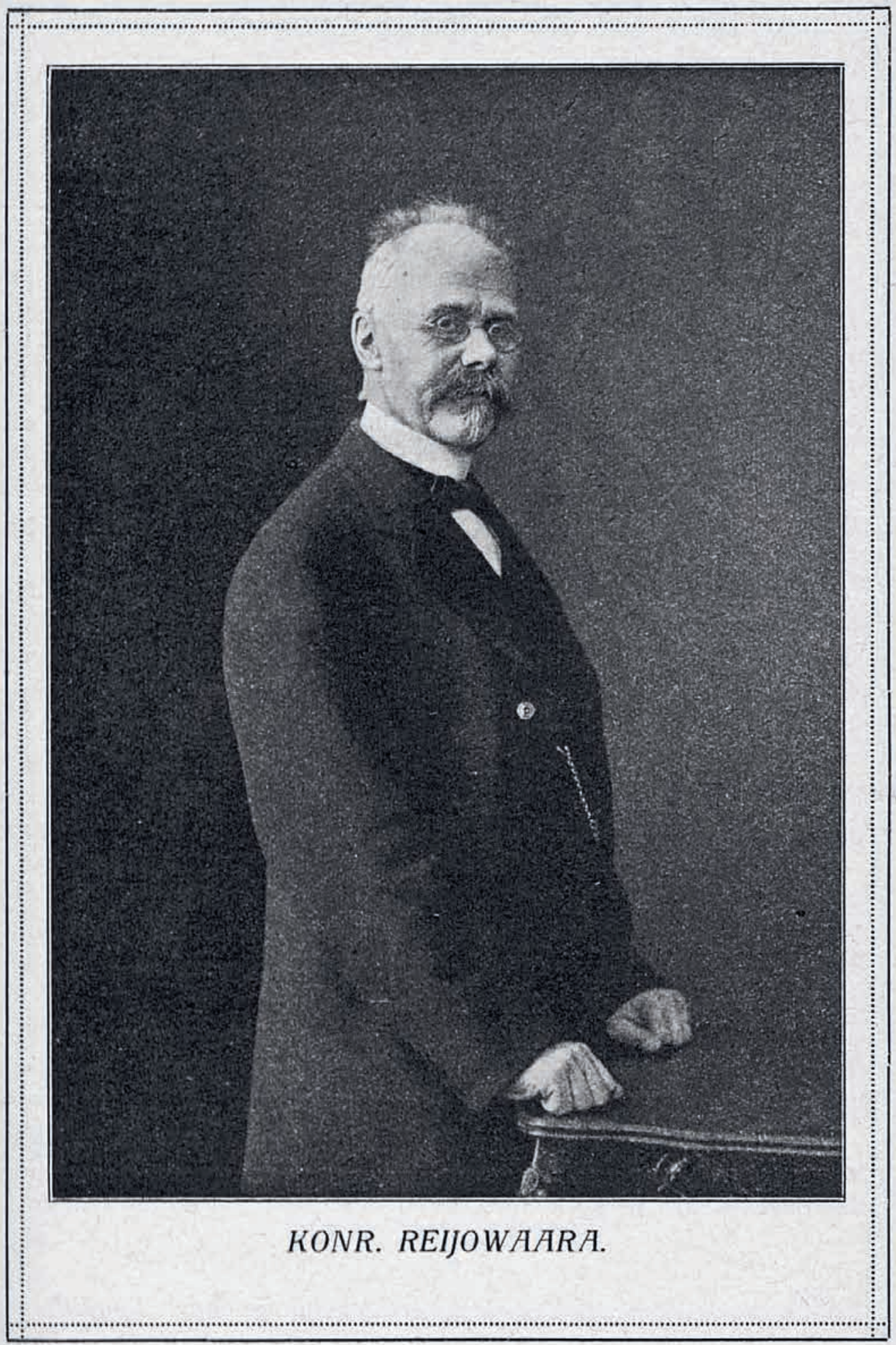


När ReijoWaara tog initiativet till FNH nämnde han inga utländska modeller, utan presenterade idén som sin egen och som en innovation som andra länder borde ta efter. ${ }^{21}$ ReijoWaara hade tidigare erfarenheter av att leda en folkrörelse. Han var ledande aktivist i en riksomfattande kampanj för nykterhetsrörelsen och ordförande för ett tidigt, icke-radikalt och lokalt arbetarförbund. Genom att planera det nya förbundet som en riksomfattande, toppstyrd organisation ledd av den utbildade eliten följde ReijoWaara de finska folkrörelsernas tradition från sent I8oo-tal. ${ }^{22}$

ReijoWaara själv intog en framstående roll som FNH:s sekreterare (I906-I9I2) och därefter som ordförande (I913-I920). Taavetti Laitinen, professor i hygien och generaldirektör för Medicinalstyrelsen, var ordförande under den period ReijoWaara var sekreterare. Andra män i liknande politisk och vetenskaplig ställning var också involverade i grundandet av FNH. Som lantdagsledamot och representant för borgarståndet (1897, I899 och 1900) var ReijoWaara även en del av den politiska eliten. Hans personliga kontakter inom statsförvaltningen och den akademiska världen gav organisationen en halvofficiell och prestigefylld roll i samhället. ${ }^{23}$ Till skillnad från övriga nordiska länder karakteriserades de finska folkrörelserna av sina nära band till den statliga byråkratin. ${ }^{24}$

Målet för FNH var att fungera som en enande kraft i samhället. Detta eftersom man var rädd för att den massiva ökningen av folkrörelser efter generalstrejken år 1905 - såsom den radikala arbetarorganisationen, partier, fackförbund och kvinnoorganisationen - skulle splittra folket och nationen. I stället för att bli enbart ytterligare en organisation som tävlade med andra organisationer om folkets stöd utformades FNH med syftet att länka samman alla medborgarorganisationer. Den lokala eliten, det vill säga "läkare, veterinär, präst, apotekare, folkskollärare, sjuksköterska, barnmorska och medlem i hälsovårdsnämnd eller fattigvårdsstyrelse", bjöds in för att leda de lokala verksamheterna. Tanken var att varje medborgarorganisation som redan fanns - exempelvis ungdoms-, nykterhets-, sport-, lantmanna-, missions-, kvinno-, arbetare-, värdinne- och husbondeförening - skulle välja två representanter för den lokala FNH-klubben. ${ }^{25}$ Även individer utan anknytning till andra organisationer kunde ansluta sig till FNH genom att betala en medlems- 
avgift. Den enda kvalifikationen för medlemskapet var ett intresse för upplysning och framåtskridande. Det finska begreppet edistys ("framåtskridande", "framsteg") omfattade den moderna framtidsvisionen med linjära framsteg. Särskilt termen edistysseura ("framåtskridande förening") anammades som ett vedertaget begrepp för alla organisationer som arbetade för nationens allmänna bästa. ${ }^{26}$

FNH förväntades överskrida alla gränser mellan människor: ”Det hygieniska väckelsearbetet inom en kommun, samt däraf härflytande åtgärder, oberoende af språk och politisk ståndpunkt, måtte bedrivas med samfällda krafter och ej splittradt." ${ }^{27}$ För att säkerställa ett brett stöd rekryterades folk ur olika samhällslager till den konstituerande kommissionen som hade 16 medlemmar. Även om den finska läkarkåren på grund av den nationalistiska språkstriden var uppdelad i två rivaliserande organisationer, hade kommissionen representanter från såväl det finskspråkiga som det svenskspråkiga läkaresällskapet. I de lokala klubbarna i tvåspråkiga kommuner förväntades de båda språkgrupperna samarbeta. ${ }^{28}$ Kommissionen hade kopplingar till arbetarklassen genom en av ledamöterna, Yrjö Sirola, som var sekreterare i det socialdemokratiska partiet och journalist för partiets huvudtidning, Työmies. Kommissionen hade också tre kvinnnliga ledamöter. Dessa var läkaren Elin Elmgren samt Alexandra Gripenberg och Hilda Käkikoski, vilka var ledande inom Finlands tidiga kvinnorörelse (Suomen naisyhdistys - Finsk kvinnoförening). De två sistnämnda representerade det nationalistiska partiet (Finska partiet) i enkammarlantdagen 1907, vilket gjorde dem till kvinnliga pionjärer inom den riktstäckande politiken. ${ }^{29}$

Att personer av båda könen deltog ansågs vara av yttersta vikt. Enligt ReijoWaara kunde hygien delas upp i två könsrelaterade sektorer. Hygien som begrepp - som på finska vanligen översattes till terveydenhoito-oppi ("hälsovårdslära"), terveysoppi ("hälsolära") eller terveydenhoito ("hälsovård") - kategoriserades som personlig respektive allmän hygien. ${ }^{30}$ Då ansvaret för den personliga hygienen låg på familjerna och individerna ansågs det ingå i kvinnans uppgifter i egenskap av hennes roll som "hemmets föreståndarinna och fostrare av det uppväxande släktet". Mannen däremot var, i egenskap av representant för staten och kommunen, ansvarig för den allmänna hygienen, som omfattade övervakning och 
juridisk reglering gällande vittomfattande miljöfrågor, såsom vatten, avfall och livsmedel. ReijoWaara betonade emellertid kopplingarna mellan de könsrelaterade hygiensektorerna:

Det skall stå klart för såväl män som kvinnor, att även i hälsovårdsarbetet måste män och kvinnor vandra hand i hand och hjälpa och komplettera varandra, om vi vill åstadkomma något verkligt helgjutet och beständigt. ${ }^{31}$

Hälsovårdsförbundet hade för avsikt att nå ut till "alla i landet", men aktiviteterna vände sig särskilt till föreningarna verksamma på landsbygden..$^{32}$ Eftersom 86 procent av befolkningen 1906 ännu levde på landsbygden var betoningen på lantbefolkningen ett uppenbart val. ${ }^{33}$ Sedan I890-talet hade dödlighetstalen indikerat sämre hälsoförhållanden i landsbygdskommunerna än i städerna. Dessutom gav hälsovårdsstadgan från I 879 hälsovårdsnämnderna ansvaret för tillsynen av hälsoförhållandena i städer, medan landsbygden blev utan nämnder. Detta resulterade i att städerna blev föregångare och modeller i hälsoarbetet och att landsbygden började förknippas med underutveckling och okunnighet. ${ }^{34}$

Trots den allmänna strävan att övertala "medlemmar i alla politiska partier, rika som fattiga, bildade som obildade" och "kvinnor som män" att delta i aktiviteten, ${ }^{35}$ pekar kategoriseringen av medlemmarna i folklager enligt ovannämnda dikotomier i sig på att initiativtagarna var medvetna om skillnaderna i fråga om klass, kön och språk. För FNH:s ledare orsakade den snabba och radikala implementeringen av det mest demokratiskt representativa systemet i Europa - med allmän rösträtt för såväl män som kvinnor 1906 - rädsla för social och politisk oro. Den opolitiska ambitionen till trots var $\mathrm{FNH}$ :s vision att upprätthålla den gällande samhällsordningen genom den borgerliga reformismen. ${ }^{36}$

\section{Misslyckande}

I september och oktober 1906 var FNH flitigt förekommande i tidningarna. ${ }^{37}$ Den ledande tidskriften för hälsoupplysning, Terveydenhoitoleht $i$ med ReijoWaara som chefredaktör (1905-19I8), var organisationens 
främsta språkrör. ${ }^{38}$ Ett stort antal tidskrifter och tidningar, inklusive arbetarklassens radikala tidning Työmies, informerade läsarna om de nya aktiviteterna. ${ }^{39}$ ReijoWaara rapporterade att den nya organisationen till och med åtnjöt erkännande i utlandet. Enligt ReijoWaara hade chefredaktören för svenska Hälsovännen, Henrik Berg, frågat sig huruvida nationen borde följa Finlands exempel och starta en liknande organisation. ${ }^{40}$

De första tecknen på svårigheter med att nå ut till alla finländare blev snart tydliga. ReijoWaara blev varse motviljan hos svenskspråkiga Hufvudstadsbladet och bristande aktivitet inom svenskspråkiga grupper. ${ }^{41}$ Detta antyder eventuellt att FNH snart identifierades som en fennomansk strävan, som i huvudsak hade stöd bland den finsktalande majoriteten. ${ }^{42}$ ReijoWaara var personligen en hängiven förespråkare för det nationella medvetandet i Finland, och han var en av de 70 ooo finländare som tog ett finskt efternamn som en del av en riksomfattande kampanj 1906. ${ }^{43}$

Rent allmänt visade sig den lokala verksamheten bli mindre aktiv än väntat. År 1908 hade 16 lokala klubbar startats, men endast 4 av dem rapporterades ha vidtagit faktiska åtgärder. ${ }^{44}$ Till exempel hade en klubb i industrisamhället Äänekoski i Mellersta Finland en lovande start under ledning av två lärare och en präst. Trots den breda representationen av olika aktörer i lokalsamhället - fabrikens sjukkassa, folkhögskolan, kvinno- och arbetarorganisationer och brandkåren - var klubben nästan obefintlig bara två år senare. ${ }^{45}$ År I9Io fanns aktiva lokala klubbar i färre än Io orter och åren I9I2-I9Is fanns aktiviteter i I6 orter. ${ }^{46}$

Den lokala klubben lockade som bäst både medlemmar och publik. En av de mest energiska klubbarna, i Kymmene i sydöstra Finland, rapporterade en imponerande mängd aktiviteter: 150 tal, 7300 åhörare och fler än 5000 utdelade broschyrer om hälsoupplysning på åtta år. ${ }^{47}$ Engagemanget i Kymmene var ändå otillfredsställande. År I9I2 tog endast ett fåtal medlemmar ansvar för verksamheten, medlemsavgifter betalades inte och ungdomarna deltog enbart i en simtävling och ignorerade övriga sammankomster. ${ }^{48}$

Den allmänna bristen på entusiasm bland allmänheten, och även bland den utbildade befolkningen, var en källa till frustration för ReijoWaara. ${ }^{49}$ På lokal nivå vädjade han till läkare om stöd, eftersom han 


\section{Finlands Nationella Hälsovàrds- förbunds härvarande filial} anordnar

sōndagen den 1 mars, lungsots-tuberkulosdagen, \& stadens folkskola

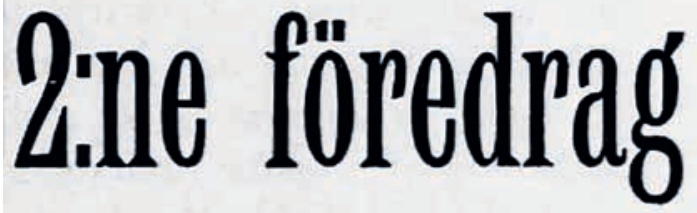

kl. 12 pa dagen svenskt föredrag om lungsoten af dokt. E. Grönberg, kl. 1 ps dagen likaså på fioska af dokt. M. Gadd.

\section{Fri entré.}

(Karj.1.1.20) 765

Bild 7.2. Finlands nationella hälsovårdsförbund i Viborg organiserade upplysningskampanjer i hälsovård både på svenska och på finska år 1908. I allmänhet kunde förbundet dock varken överskrida språkgränser eller politiska skillnader. Källa: Wiborgs Nyheter 29 februari 1908/Digitala samlingar, Finlands nationalbibliotek.

hade mottagit klagomål om deras svala attityd. ${ }^{50}$ En lokal klubb rapporterade om en ny kommunalläkare som inte var villig att ansluta sig till rörelsen. "Framtiden ser mörk ut, eftersom den tidigare ordföranden och sekreteraren har flyttat", klagade en annan lokal klubb. ${ }^{51}$ När kommunalläkarna såsom alla kommunala tjänstemän fick ett större antal förtroendeuppgifter i den växande lokalförvaltningen förmodas det ha lett till att de lämnade organisationen. ${ }^{52}$

Generellt sett tvingade den snabba utvecklingen inom föreningslivet, som till och med små landsbygdssamhällen stod inför, folk att välja och prioritera. ${ }^{53}$ Eftersom FNH:s agenda inte var högsta prioritet för representanterna från de olika organisationerna investerade de förmodligen mer tid och energi i sina egna organisationer. Medlemsantalet i andra opolitiska, överbryggande organisationer med fokus på självbildning, såsom nykterhetsrörelsen, stod också inför en nedåtgående 
trend. ${ }^{54}$ Istället började de nya organisationerna, som baserades på kön, klass och modern partipolitik, bygga nya typer av tillhörighet, aktörskap och identiteter. Arbetarklassens kvinnor bröt till exempel med kvinnorna från överklassen i rösträttsrörelsen år 1905, och förenade sig istället med arbetarklassmännen för att säkerställa allmän rösträtt och en enkammarlantdag. ${ }^{55}$ Vid sidan av den politiska kontroversen mellan socialister och icke-socialister delade icke-socialister upp sig i två sinsemellan rivaliserande läger. ${ }^{56}$ Den socialt breda FNH-klubben i Tyrvändö kunde till exempel samla de lokala organisationerna som verkade för nationalism, nykterhet, kristendom och arbetarklass. Den politiska gruppen Ungfinska partiet anslöt sig däremot inte till rörelsen. ${ }^{57}$ En möjlig förklaring till att FNH inte fick ett utbrett stöd var att folket började få nya förväntningar på relationen individen-samhället samt nya prioriteringar gällande hälsofrämjandet.

\section{Ett konkurrerande scenario - sociala reformer som vägen till ett sunt samhälle}

Jag undrar om nykomlingen $[\mathrm{FNH}]$ har några egentliga avsikter eller om den används för att styra bort folks tankar från verkligt effektiva, genomgripande sociala reformer. Vi får vänta och se. ${ }^{58}$

De skeptiska men samtidigt en aning hoppfulla kommentarerna om det nya förbundet i den socialdemokratiska tidningen Eteenpäin (1908) speglar arbetarrörelsens tudelade förväntningar på hälsoupplysningen. I sin forskning om arbetarklassens kvinnor i Finland har Riitta Oittinen poängterat hur hoppet om en bättre framtid gjorde att hälsoinformation accepterades, men att medelklassens moraliserande budskap ofta möttes av motvilja och kritik. ${ }^{59}$ Hälsoutbildare attackerades i arbetarklassens tidningar för ignorans och bristande omdöme:

I dylika fall, där överansträngning, dålig mat, dåliga bostadsförhållanden, ohälsosam luft på arbetsplatsen och många andra orsaker främjar sjukdomar, kännes det stundom som ett hån att höra om vårt borgerskaps förehavanden i fråga om bekämpning av sjukdomar. ${ }^{60}$ 
Vem av oss har inte upplevt de beskyllningar som arbetarbefolkningen alltsomoftast utsätts för, när den påstås lägga så ringa vikt vid hälsovården. [...] En sådan omsorg om den fattiges hälsa betyder föga, som bara innehåller råd som inte kan förverkligas. ${ }^{61}$

I stället för att fokusera på fostran och upplysning ansåg arbetarrörelsen att bättre bostäder, arbetsförhållanden och näring gav bättre förutsättningar för hälsa och renlighet. Arbetarklassen krävde samhällsreformer för att undvika tuberkulos och andra folksjukdomar:

Det är med den här folksjukdomen som med de flesta lidanden, som mest tynger de klasser som saknar egendom; orsakerna till dem är de samhälleliga förhållandena, de lägre klassernas fattigdom och glädjelösa liv. Därför är de inte fullständigt överstigliga [...] innan förhållandena har utvecklats så, att även de som nu trängs på skuggsidan har fått se dagsljus. ${ }^{62}$

Ur arbetarklassens perspektiv var en organiserad arbetarrörelse för samhälleliga reformer det enda effektiva verktyget för bättre folkhälsa. ${ }^{63}$

Arbetarnas krav fick positivt gensvar i medicinska kretsar. Den internationellt erkände finske professorn och hygienförespråkaren Albert Palmberg betonade efter storstrejken I905 vikten av att lösa de sociala problemen inom samhällets lägre klasser:

Det jubel öfver återvunnen frihet, som gripit alla sinnen, har dock tyvärr grumlats af det hat och den bitterhet hos de lägre klasserna mot de bildade, som under dessa dagar på flere sätt kommit i dagen.

Det är nu alldeles nödvändigt, att till granskning upptaga orsakerna till denna bitterhet, och där den beror på sociala missförhållanden, som förut icke vunnit tillbörligt beaktande, undanrödja desamma. ${ }^{64}$

Palmberg kritiserade kampen mot tuberkulos för att den endast fokuserade på individen och ignorerade det sociala. Han lyfte fram de "skrämmande" bostadsförhållandena i Helsingfors, där 22000 invånare levde i mörka, fuktiga och kalla bostäder, och frågade sig:

Om vi tänka oss i dessa arbetares ställning, skulle vi knota däröver, eller skulle vi det icke? Det är fåvitskt att tro, att man genom införande 
af spottlådor och spottkoppar skall råda bot på sådana missförhållanden. Hvart kommer man med att bygga sanatorier för sjuka från sådana hem? ${ }^{65}$

Förutom arbetarfrågan och det faktum att en tredjedel av invånarna i landets största städer upplevde trångboddhet var de jordlösas bostadssituation på landsbygden en lika aktuell fråga. Nästan en femtedel av hushållen på landsbygden levde utan permanent bostad, vilket ledde till ökad emigration och inflyttning till städer i början av 1900-talet. ${ }^{66}$

Distriktsläkaren N. J. Arppe såg sociala reformer som en förutsättning för bättre hälsa bland arbetarklassen:

Hälsovård och arbetarfrågan [...] är barn av samma tid, framsprungna ur samma jord [...] Många av arbetarnas krav, som vid första anblicken ter sig orimliga, blir skäliga och rättmätiga i ljuset av hälsovården. ${ }^{67}$

Arppe lyfte fram moderskapsledighet och nationell socialförsäkring för arbetslösa och arbetsoförmögna som reformer som borde förespråkas av hälsovårdsorganisationer. År 1907 introducerade han social hygien som en ny vetenskaplig disciplin, vilken syftade till att lösa hälsorelaterade samhällsproblem. Han kallade social hygien för "samhällelig hälsovård" (yhteiskunnallinen terveydenhoito) för att särskilja den från privat och allmän (statlig) hälsovård (hygien). ${ }^{68}$ Enligt medicinalrådet Akseli Koskimies (I9I6) fokuserade den sociala hygienen på individen som medlem av en samhällsklass eller en ekonomisk grupp, medan allmän hygien såg på individen som en medlem av en stat eller en region. Precis som arbetarklassens förkämpar betonade den sociala hygienen att hälsorelaterad ojämlikhet kunde kopplas till sociala hierarkier inom de olika folklagren. ${ }^{69}$

I motsats till sina kollegor var FNH:s ledargestalt, ReijoWaara, ovillig att acceptera den nya idén om social hygien. Anssi Halmesvirta har till exempel påpekat att problemen inom den urbana arbetarklassen aldrig gavs någon större uppmärksamhet i ReijoWaaras texter. Detta trots att han innehade en statlig tjänst som distriktsläkare i Helsingfors. ${ }^{70}$ År 1907 kritiserade tidningen Työmies ReijoWaara för hans borgerliga "hycklande" och "idealistiska" hållning. Enligt tidningen stämplade ReijoWaara socialistiska idéer som hat och förföljelser utan att inse att 
socialisterna byggde upp ett nytt samhälle. ${ }^{71}$ Även FNH blev måltavla för kritiken. Tidningen Sosialisti rapporterade I9I I om förbundets statliga subventioner under den svidande rubriken "Herrars hälsa vårdas" ${ }^{72}$ På liknande sätt fördömdes initiativet till en lokal FNH-klubb i Alavo som borgerligt och ofruktsamt, då det bortsåg från arbetarklassens reella problem. ${ }^{73}$ Den radikala arbetarklassens socialistiskt drivna kritik ignorerades emellertid av ReijoWaara. Utifrån sin konservativa, kristna världsbild ansåg han att det var individens fysiska och psykiska sjukdomar och moraliskt tveksamma levnadssätt snarare än samhällets socioekonomiska strukturer som var huvudorsaken till de sociala problemen. Under sina senare år kopplade ReijoWaara hygien i allt större utsträckning till moralisk renlighet och undvikande av synd. ${ }^{74}$

\section{Tillgång till hälsovårdstjänster som statligt ansvar}

Tilltron på en ny framtida samhällsstruktur bidrog till att prioriteringen av hälsoupplysning i stället för hälsovårdstjänster ifrågasattes av FNH:s kritiker. ReijoWaara identifierade också själv behovet av hälsovårdstjänster och förespråkade till exempel statliga subventioner för anställning av lokalt placerad medicinsk personal och för byggande av sanatorier. ${ }^{75}$ Trots det dömde han ut alla slags lagstadgade skyldigheter för lokala myndigheter att ordna hälsovårdstjänster som förhastade och olämpliga tills en lokal frivillig strävan till hälsa hade väckts. ReijoWaara menade att folkhälsoarbetet $\mathrm{i}$ annat fall riskerade att motarbetas och därmed förbli fruktlöst. ${ }^{76}$

Hälsoupplysningens prioriteringar delades inte av allmänheten, vars missnöje främst gällde bristen på sjukvård..$^{77}$ En medborgarorganisation sade till exempel upp medlemskapet i en lokal FNH-klubb "eftersom hälsovårdsförbundet inte har varit till någon nytta, och vi fortfarande har varit tvungna att vända oss till en läkare när vi har varit sjuka”.78 Förtvivlan över den dåliga tillgången till hälso- och sjukvårdstjänster rapporterades av den kortlivade FNH-klubben i Äänekoski:

Hälsoförhållandena är numera särskilt oroande här. Strypsjuka och difteri har hela hösten och vintern spridit sig, och framför allt ett stort antal barn har avlidit. Nu har vi varit tvungna att stänga folkskolorna 
ett tag. Vi har inga sjukrum, sköterskor, doktorer, apotek. Bara en fältskär, som jobbar på fabriken, försöker hjälpa till [...] i händelse av sjukdomar. Vi måste beställa mediciner från Jyväskylä. Distriktsläkare Warén har besökt oss en gång i månaden, men han flyttade till Salo för en kort tid sedan. ${ }^{79}$

I allmänhet fanns barnmorskor tillgängliga för färre än 40 procent av de kvinnor som skulle föda, och endast hälften av landsbygdskommunerna hade en anställd kommunalläkare i9ıo. En femtedel av landsbygdskommunerna var ännu på I930-talet tvungna att klara sig utan praktiserande läkare. ${ }^{80}$

Även om konkreta åtgärder för hälsovårdstjänster inkluderades i FNH:s omfattande handlingsplan, betonades att den huvudsakliga och mest brådskande uppgiften var att sprida hälsokunskap. Varje lokal klubb uppmanades dock att välja vilka andra uppgifter de prioriterade. ${ }^{81}$ Det verkar särskilt som om lokala FNH-klubbar med representanter från arbetarklass hade viljan att inleda och stödja de lokala hälso- och sjukvårdstjänsterna. Till exempel försåg en av de mest långlivade lokala klubbarna från Tyrvändö den kommunala barnmorskan med linne till fattiga kvinnor som skulle föda samt förespråkade offentlig anställning av en hälsosyster. ${ }^{82}$ I Alavo ordnade den lokala klubben I9I5 med en sjukskötersketjänst genom att tillhandahålla gratis uppehälle och skjutsar. ${ }^{83}$

I stället för sporadiska hälsovårdstjänster som initierades av medborgarorganisationer eller privata insatser krävde det socialdemokratiska partiet offentliga hälso- och sjukvårdstjänster. Enligt partiprogrammet I903 var det statens och kommunernas ansvar att tillhandahålla dem kostnadsfritt. ${ }^{84}$ Detta radikala framtidsperspektiv utmanade FNH:s ambition att väcka acceptans för hälsokunskap utan att garantera tillgänglig hälso- och sjukvård.

\section{Efter I9I8 - mot nya metoder för hälsomedborgarskap}

Efter inbördeskriget I9I 8 var det huvudsakliga dilemmat hur man skulle överbrygga klyftan mellan vinnarna och förlorarna - de borgerliga vita och arbetarklassens röda - i den nya självständiga staten. Frågor om vem 
som hörde till nationen och vilka krav som borde ställas på medborgarna och staten i fråga om hälsa skallade i det politiskt splittrade landet. ${ }^{85}$

Hälsofrämjandet gavs en viktig roll i försöken till enande strax efter kriget. Både ReijoWaara och Taavetti Laitinen - före detta ordförande för FNH och direktör för Medicinalstyrelsen - vände sig till en tidigare lösning. Omstarten av det stagnerade FNH sågs som ett steg i riktning mot en harmonisk framtid:

[D]e på många sätt upprörda och politiserade sinnena måste igen inriktas på ett verkligt nyttigt och uppbyggligt frivilligt arbete. För att uppnå detta ska det länge slumrande Finlands nationella hälsovårdsförbund uppväckas till energisk verksamhet. Genom det kan medborgare med folkets bästa för ögonen på olika områden åter finna varandra i detta harmoniska och folkuppfostrande framstegsarbete. ${ }^{86}$

I den planerade omstarten av förbundet beskrevs barnen som den viktigaste målgruppen. ${ }^{87}$ Barnen ansågs befinna sig bortom de politiska oenigheterna och utgjorde också den minst kontroversiella frågan i arbetet för att ena nationen och skapa en ljusare framtid..$^{88}$

Rekonstruktionen av FNH vann ingen mark i den nya sociopolitiska omgivningen. Tvärtom avvecklades förbundet 1920. Dessutom avtog traditionen med hälsoupplysningstidskrifter: upplagan av den ledande tidskriften, Terveydenhoitolehti, sjönk från Io ooo till 3 ooo under åren I9I3-1920, och den svenska tidskriften Tidning för Hälsovård lades ner. ${ }^{89}$ ReijoWaara, hälsoupplysningens fader, lämnade posten som chefredaktör för Terveydenhoitolehti 1918 vid 65 års ålder. Detta har tolkats som ett starkt ställningstagande mot tudelningen av folket. ${ }^{90}$

I människors vardag visade sig den politiska tudelningen som två separata världar: båda politiska sidorna hade sina egna kooperativa livsmedelbutiker och föreningshus, och alla frivilliga organisationer, från idrottsföreningar till nya organisationer för barnskydd, splittrades i två motsatta politiska läger på 1920-talet. Som ett resultat av den kontroversiella språkfrågan introducerades I92I den nya organisationen Folkhälsa, med särskilt fokus på främjande av "livskraften" hos den svenskspråkiga minoritetsbefolkningen i Finland. ${ }^{11}$ 
I det nya politiska klimatet fick lokala medborgarorganisationer inte längre rollen som den huvudsakliga lösningen inom hälsofrämjandet. I stället blev den statliga hälsopolitiken den ledande visionen. Kansanterveys ("folkhälsa") blev det styrande begreppet inom hälsopolitiken, och hela nationen blev, oberoende av social klass, målgrupp för hälsofrämjandet. Folkhälsa beskrevs som statens ansvar, vilket var ett tecken på en betydande ideologisk förändring; ändå ansågs staten ännu under tidigt I920-tal vara långsam, oflexibel och byråkratisk. På I940-talet karakteriserades emellertid statliga aktiviteter som pålitliga, bestämda, enhetliga och stående över politiska dispyter. Förändringen reflekterade en ny idé om staten som övervakare av det gemensamma bästa. I sin epokgörande bok om socialpolitik (I93I) skrev Eino Kuusi, professor och ledande tjänsteman inom socialadministrationen, att idén om staten som ett nödvändigt och välgörande verk var en förutsättning för konstruktionen av en enhetlig nation. Hälsans allt större vikt på den nationella politiska dagordningen hängde ihop med integrationen av det socialdemokratiska partiet i offentlig förvaltning samt socialdemokraternas och den agrara centerns samverkan i regeringen (I937). ${ }^{92}$

I praktiken började byggandet av riksomfattande kommunala hälsooch sjukvårdstjänster gradvis på 1920-talet. Ett stort antal lagar antogs för att implementera det nya sättet att tänka om folkhälsa på lokal nivå och för att säkerställa jämlik regional tillgång till hälso- och sjukvårdstjänster. Kommunerna var skyldiga att utnämna barnmorskor (I920, I936, 1944), kommunalläkare (I943) och hälsosystrar (I944), och att inrätta mödra- och barnvårdskliniker (I944) och ett visst antal sjukhusbäddar. De nya förebyggande tjänsterna var i huvudsak avgiftsfria, vilket återspeglar det växande offentliga ansvaret för hälsan.

Det ansågs att personliga kontakter mellan familjer och kommunal hälsovårdspersonal, via lättillgängliga, lokala tjänster, var det mest effektiva sättet att främja hälsan. De nya kvinnliga experterna, barnmorskor och hälsosystrar, såg upplysning som sin huvuduppgift och renlighet som första prioritet. Till exempel strävade hälsosystrar efter att nå ut till "så många individer och hem som möjligt för att smyga in nya idéer om hälso- och sjukvård". ${ }^{33}$ De nya och rena lokaliteterna, hälsohusen, 


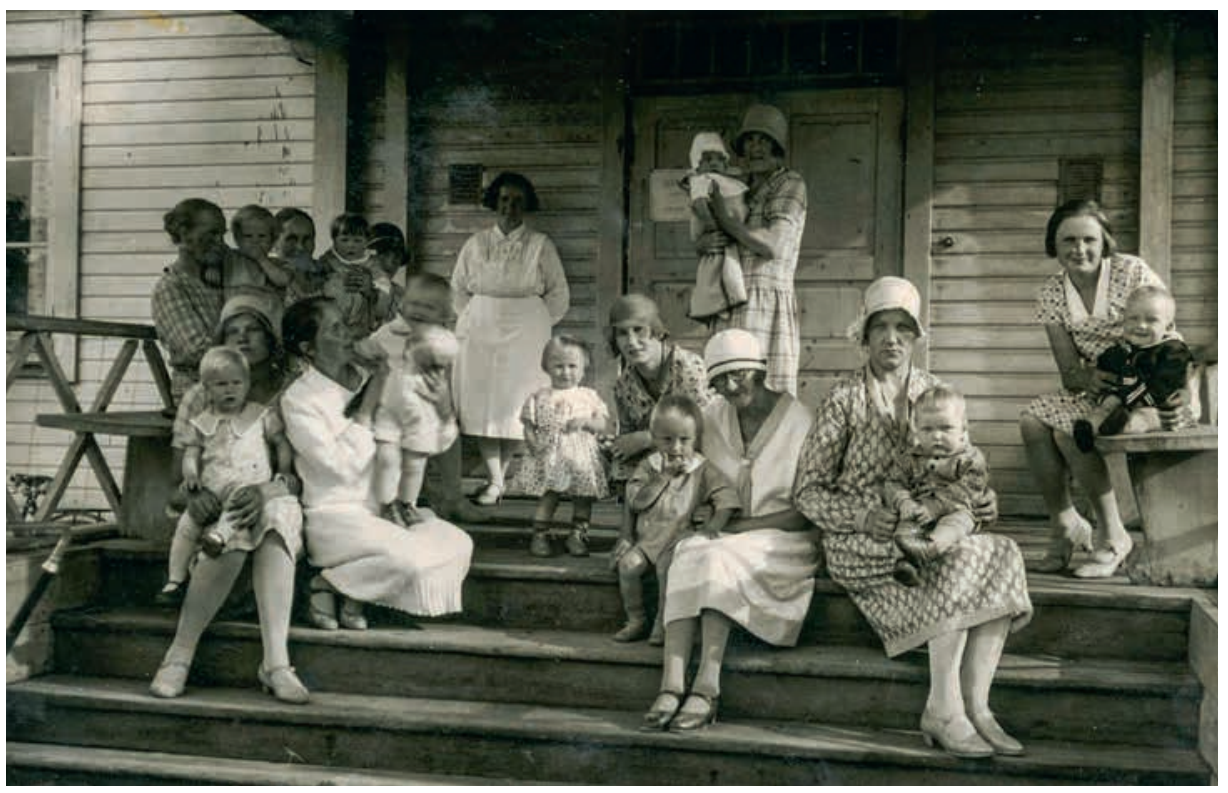

Bild 7.3. Mödrar med sina barn tillsammans med hälsosystern utanför en hälsoklinik 1930. Tillgång till hälsovårdstjänster blev en ny prioritering inom hälsopolitiken i Finland på I920-talet. Källa: Arbetarmuseet Werstas/fotograf okänd.

som byggdes överallt i landet och som utrustades med modern design, var motsatsen till smuts och fattigdom. ${ }^{94}$

Det växande utbudet av offentliga hälso- och sjukvårdstjänster var kopplat till utökade tvångsåtgärder, vilket avslöjade det komplexa förhållandet mellan rättigheter och skyldigheter. Medborgare var skyldiga att använda de nya hälso- och sjukvårdstjänsterna, särskilt i händelse av epidemier, könssjukdomar och tuberkulos. Dessutom riktade den framväxande nya hygiensektorn, som kallades rashygien, tvångsåtgärder mot individer som ansågs vara en börda för samhället. Ett mjukare sätt att styra folket var sammankopplingen av hälsotjänster och socialbidrag: gravida kvinnor var skyldiga att besöka mödravårdskliniken för att få moderskapsbidrag från I949. Eftersom alla barn och mödrar, oberoende av deras förmögenhet, sociala klass och bostadsort, försågs med hälsotjänster integrerades alla familjer i den kommunala hälsovården för att lära sig förutsättningarna för hygieniskt medborgarskap. I praktiken 
blev medborgarorganisationer integrerade i den statliga verksamheten, eftersom Medicinalstyrelsen i början av I940-talet tog över uppgiften att samordna arbetet i frivilligorganisationerna. ${ }^{95}$ Eftersom lokala kommuner i huvudsak tog över den förebyggande hälsovården minskade medborgarorganisationernas roll på 1950-talet. ${ }^{96}$

\section{Sammanfattning}

Finlands nationella hälsovårdsförbunds kortvariga existens, från 1906 till 1920, tycks ha en förklaring i den förändrade synen på relationen mellan individen och samhället, vilken resulterade i en ny riktning där staten tog allt större ansvar för individen. ReijoWaaras idé om hälsomedborgarskap med lokala klubbar för medborgerligt hälsofrämjande arbete var otidsenlig redan vid förbundets grundande. FNH:s aktivitet, som leddes av medelklassen, utgick från den hierarkiska idén om ståndssamhället. Förbundet ansåg att allmogen bestod av okunniga individer som behövde hälsoupplysning och handledning, och ville höja dem till den nivå av ansvar och medvetenhet som medborgarskapet krävde. Förbundet strävade efter en ren, stark och harmonisk nation genom att förändra individens livsstil och göra hälsa till en personlig skyldighet gentemot nationen. Idén om ett förenande förbund och samarbete bortom klass och stånd stod emellertid i strid med den nya uppdelningen mellan "vi" och "de" som växte fram i samhällets övergång till ett demokratiskt styre i början av I9oo-talet.

Den nya tolkningen av relationen mellan individen och samhället utmanade FNH:s vision. Socialdemokratin riktade kritik mot den borgerliga reformismen. Istället för personlig hygien var det social hygien med strukturella sociala reformer som blev nyckeln till hälsa, renlighet och en enad nation. När staten tog ansvaret för folkets hälsa blev tillgången till offentliga hälso- och sjukvårdstjänster högsta prioritet. Den könsrelaterade idén om att kvinnan hade ett särskilt ansvar för renligheten upprätthölls av de nya kvinnliga experterna inom hälsovården.

De två skilda och konkurrerande formuleringarna av hälsomedborgarskap i början av I900-talet kan ses som historiska lager av erfarenheter. De båda erfarenhetslagren med sina olika synsätt på relationen mellan 


\section{individ och samhälle existerade parallellt. Eftersom de båda formulering- arna av hälsomedborgarskap finns lagrade i hälsofrämjandets praktiker finns de kvar och forsätter att konkurrera inom den finska hälsovården.}

\section{Noter}

I ReijoWaara, Konrad, "Liittoon nuoret ja vanhat Suomen kansan terveyttä suojelemaan ja nostamaan I", Terveydenhoitolehti, vol. I8, nr 7-8, I906, IoI; ReijoWaara, Konrad, "Liittoon nuoret ja vanhat Suomen kansan terveyttä suojelemaan ja nostamaan II", Terveydenhoitolehti, vol. I8, nr 9, I906, I29-I34; Hietala, Marjatta, "ReijoWaara, Konrad", Kansallisbiografia-verkkojulkaisu, Studia Biographica 4, Helsingfors: SKS, 20I5, http://urn.fi/urn:nbn:fi:sks-kbg-006346 (senast kontrollerad II juni 202I); Ignatius, Jaakko, Suomalainen lääkäriseura Duodecim I88I-2006 I-II, Helsingfors: Duodecim, 2012, I26-I30.

2 "Uppmaning", Nya Pressen 25 september 1906, nr 260B, I.

3 Alapuro, Risto \& Stenius, Henrik (red.), Nordic associations in a European perspective, Baden-Baden: Nomos, 20Io; Sundin, Jan, "Folkhälsa och folkhälsopolitik", Svenska folkets hälsa i historiskt perspektiv, Hogstedt, Christer, Lindberg, Jakob \& Moberg, Henrik (red.), Stockholm: Statens folkhälsoinstitut, 2005, 386, 407; Vallgårda, Signild, Folkesundhed som politik: Danmark og Sverige fra I930 til idag, Århus: Aarhus Universitetsforlag, 2003, 30; Schiøtz, Aina, ”De frivillige organisasjonene og helsebyggeriet i Norge", Rom for helse: Hovedtrekk i spesialisthelsetjenestens bygningshistorie, Hammer, Erlend \& Oftedal, Marte (red.), Oslo: Helse og omsorgsdepartementet, 20I2, 99-I I 4.

4 Oker-Blom, Max, "Till frågan om 'läkartätheten' och läkarbehovet i Finland", Suomen yleinen lääkäriliitto. Tiedonantoja liiton jäsenille, vol. 2, nr 2, 1916, 56; Harjula, Minna, Hoitoonpääsyn hierarkiat: Terveyskansalaisuus ja terveyspalvelut Suomessa I9oo-luvulla, Tammerfors: Tampere University Press, 2015, 68-85, I46.

5 Buchardt, Mette, Markkola, Pirjo \& Valtonen, Heli, "Introduction: Education and the making of the Nordic welfare states", Education, state and citizenship, Buchardt, Mette, Markkola, Pirjo \& Valtonen, Heli, (red.), Helsingfors: Nordic Centre of Excellence NordWel, 2013, 7-30. På 1910-talet gick 75 procent av barnen i södra Finland i folkskolan, men i norra Finland var siffran bara 30 procent. Kaarninen, Mervi, Nykyajan tytöt: Koulutus, luokka ja sukupuoli I920- ja I930-luvun Suomessa, Helsingfors: SHS, 1994, 23.

6 ReijoWaara, Konrad, "Kertomus Suomen kansallisen Terveysliiton synnystä, kehityksestä ja toiminnasta I906-I910", Duodecim, vol. 26, nr I0, I910, 403-44I; Halmesvirta, Anssi, "Kansallisen vastustuskyvyn puolesta: Konrad ReijoWaara ja degeneraation idea I880-1918", Historiallinen arkisto I05, Helsingfors: SHS, I995, I3-69; Harjula, Hoitoonpääsyn hierarkiat, 47-53.

7 Helén, Ilpo \& Jauho, Mikko, ”Terveyskansalaisuus ja elämän politiikka”, Kansalaisuus ja kansanterveys, Helén, Ilpo \& Jauho, Mikko (red.), Helsingfors: Gaudeamus, 2003, 13-32; Porter, Dorothy, Health citizenship: Essays in social medicine and biomedical politics, San Francisco: University of California Medical Humanities Press, 20I I; Ryymin, Teemu, "'Health citizenship' - a short introduction", Citizens, courtrooms, crossings, Andresen, Astri et al. (red.), Conference proceedings, Report ro, Bergen: 
Stein Rokkan Centre for Social Studies, 2008, I5-20, https://norceresearch.brage.unit. no/norceresearch-xmlui/handle/I I250/2628252 (senast kontrollerad II juni 202I).

8 Berger, Peter \& Luckmann, Thomas, The social construction of reality: A treatise in the sociology of knowledge, London: Penguin Books, I99I(1966); Koselleck, Reinhart, Futures past: On the semantics of historical time, New York: Columbia University Press, 2004; Annola, Johanna et al. (red.), Eletty historia: Kokemus näkökulmana menneisyyteen, Tammerfors: Vastapaino, 2019; Kettunen, Pauli \& Petersen, Klaus (red.), Beyond welfare state models: Transnational historical perspectives on social policy, Cheltenham: Edward Elgar, 20II, 3-7.

9 Harjula, Hoitoonpääsyn hierarkiat, 3If.; Alapuro, Risto et al. (red.), Kansa liikkeessä, Helsingfors: Kirjayhtymä, 1987; Haapala, Pertti et al. (red.), Kansa kaikkivaltias: Suurlakko Suomessa I905, Helsingfors: Teos, 2008.

ıo ReijoWaara, Konrad, "Piirteitä terveydenhoitoaatteen kehityksestä Suomessa", Duodecim, vol. 22, $\mathrm{nr}$ II, 1906, 280.

I I ReijoWaara, Konrad, "Puhtauden puute tappioiden ja vastuksien syynä", Terveydenhoitolehti, vol. I7, nr 9, I905, I4If.

I2 ReijoWaara, Konrad, "Kirja-arvostelua", Terveydenhoitolehti, vol. I8, nr 7-8, I906, I $24 \mathrm{f}$.

I3 "Uppmaning", I; ReijoWaara, "Kertomus Suomen kansallisen", Duodecim, 4I8-425.

I4 Kuusikari, Sanna, "Jokiwesi ja hywä hoito": Porin yleiset saunat I860-I9Io. Pro gradu-avhandling i historia vid Tammerfors universitet, 20I7; Oker-Blom, Max, "Sananen suomalaisesta saunasta", Terveydenhoitolehti, vol. I3, nr 8-9, I90I, I23-I26; Taskinen, K. "Suomalaisesta saunasta", Terveydenhoitolehti, vol. 22, nr 9, I9I0, I36f.; ReijoWaara, Konrad, "Mitä varten käytte saunassa?", Terveydenhoitolehti, vol. 30, nr I, I9I 8, 8-IO; Mustajoki, Pertti, Mies, joka hakkasi halkoja: Terveysapostoli Konrad ReijoWaara, Helsingfors: Duodecim, 2013, 278-287.

Is Runeberg, J. W., "Tuberkuloosi kansantautina ja sen vastustaminen", Valvoja, vol. 23, nr 7-8, 1903, 404; ReijoWaara, "Kertomus Suomen kansallisen", Duodecim, 403f.; Jauho, Mikko, Kansanterveysongelman synty: Tuberkuloosi ja terveyden hallinta Suomessa ennen toista maailmansotaa, Helsingfors: Tutkijaliitto, 2007, 348-37I; Harjula, Hoitoonpääsyn hierarkiat, 40-46.

I6 Hietala, Marjatta, Innovaatioiden ja kansanvälistymisen vuosikymmenet: Tietoa, taitoa, asiantuntemusta I. Helsinki eurooppalaisessa kehityksessä I875-19I7. Hist. Arkiv 99:I. Helsingfors: SHS \& Helsingin kaupungin tietokeskus, I992, 9If., I Iof.; Halmesvirta, "Kansallisen vastustuskyvyn", I5-18, 29; Mustajoki, I37-160, 407.

I7 Liikanen, Ilkka, "Kansa", Käsitteet liikkeessä: Suomen poliittisen kulttuurin käsitehistoria, Hyvärinen, Matti et al. (red.), Tammerfors: Vastapaino, 2003, 257-307; Stenius, Henrik, "Kansalainen", Käsitteet liikkeessä: Suomen poliittisen kulttuurin käsitehistoria, Hyvärinen, Matti et al. (red.), Tammerfors: Vastapaino, 2003, 309-362; Harjula, Minna, "Universal, but exclusive? The shifting meanings of pre- and post-war public health in Finland", Conceptualising public health: Historical and contemporary struggles over key concepts, Kananen, Johannes, Bergenheim, Sophy \& Wessel, Merle (red.), London: Routledge, 2018, 6I-75; Mustajoki, 73f.

I8 "Suomen kansallisen terveysliiton säännöt", Terveydenhoitolehti, vol. 20, nr 6, I908, 96.

I9 "Uppmaning", I; ReijoWaara, Konrad, "Suomen kansallisen terveysliiton paikallisjärjestöjen työsuunnitelmasta", Terveydenhoitolehti, vol. 21, nr 6, I909, 82. 
20 ReijoWaara, Konrad, ”Mitä voisi ja mitä tulisi Duodecim-seuran tehdä käytännöllisen terveydenhoitotyön edistämiseksi maassamme?", Duodecim, vol. 26, nr 5, I910, I53f.; Sulkunen, Irma, Raittius kansalaisuskontona: raittiusliike ja järjestäytyminen I870-luvulta suurlakon jälkeisiin vuosiin, Helsingfors: SHS, 1986, 38-39; Jauho, 348-352.

2I ReijoWaara, Konrad, "Liittoon nuoret ja vanhat I", 97-IOI; ReijoWaara, Konrad, "Liittoon nuoret ja vanhat II", I29-I34; ReijoWaara, Konrad, "Ruotsissa saavuttaa Suomen kansallinen terveysliittoaate tunnustusta", Terveydenhoitolehti, vol. I9, nr I I, 1907, I70f.; Mustajoki, 319-322.

22 Hietala, Innovaatioiden, I I I, 233; Hietala, "ReijoWaara, Konrad"; Halmesvirta, "Kansallisen vastustuskyvyn", 57f.; Haapala, Pertti, Kun yhteiskunta hajosi: Suomi I9I4-I920, Helsingfors: Painatuskeskus, 1995, 40-46; Sulkunen, Raittius kansalaisuskontona, 37-39, 47-68, 9I-93, 221, 228; Ignatius, I29f.

23 ReijoWaara, "Kertomus Suomen kansallisen", Duodecim, 405, 409; Ruotsalainen, Armas, "Kertomus Suomen kansallisen terveysliiton toiminnasta vuosina I9I 2-I9I5", Terveydenhoitolehti, vol. 28, nr 7-8, I916, I22; Mustajoki, 322-332; Jauho, I88f.

24 Männikkö, Ilkka, "Making the people fit for democracy: Kansanvalistusseura and popular adult education in Finland after the general strike of 1905 ", Nordic lights: Education for nation and civic society in the Nordic countries, 1850-2000, Ahonen, Sirkka \& Rantala, Jukka (red.), Helsingfors: SKS, 200I, 5I-79.

25 "Uppmaning", I.

26 "Suomen kansallisen terveysliiton säännöt", Terveydenhoitolehti, vol. 20, nr 6, I908, 95f.; "Uppmaning", I; ReijoWaara, "Liittoon nuoret ja vanhat II", I32.

27 "Uppmaning", I.

28 ReijoWaara, "Kertomus Suomen kansallisen", Duodecim, 404; Nyström, Samu, "Suomen Lääkäriliitto sata vuotta", Vapaus, terveys, toveruus: Lääkärit Suomessa I9Io-20Io, Nyström (red.), Helsingfors: Fennomed, 2008, 21; Hietala, Marjatta, "Laitinen, Taavetti", Kansallisbiografia-verkkojulkaisu, Studia Biographica 4, Helsingfors: SKS, 2008, http://urn.fi/urn:nbn:fi:sks-kbg-0033I7 (senast kontrollerad II juni 202I); Ignatius, I3 I-I36; "Uppmaning", I.

29 ReijoWaara, "Kertomus Suomen kansallisen", Duodecim, 404f.; Markkola, Pirjo \& Ramsay, Alexandra (red.), Yksi kamari-kaksi sukupuolta: Suomen eduskunnan ensimmäiset naiset, Helsingfors: Riksdagsbiblioteket, 1997; Sainio, Venla, "Sirola, Yrjö", Kansallisbiografia-verkkojulkaisu, Studia Biographica 4, Helsingfors: SKS, 200I, http:// urn.fi/urn:nbn:fi:sks-kbg-0022I6 (senast kontrollerad I I juni 202I).

30 "Uppmaning", I; Duodecimin sanaluettelo Suomen lääkäreille, Helsingfors: Duodecim, I898, 33; M. O-B., "Hygienia", Tietosanakirja III, Helsingfors: Otava I9I I; M. O-B., "Terveysoppi l. hygienia", Tietosanakirja IX, Helsingfors: Otava I9I7, I 452f.; Laitinen, Taavetti, "Terveysopin eli hygienian merkityksestä", Valvoja, vol. 22, nr I0, I902, $605 f$.

3I Relander, Konrad, "Terveydenhoidon tarkoitus ja tuloksia", Terveydenhoitolehti, vol. Io, nr I, I898, 5f.; Mustajoki, 70, I03.

32 "Uppmaning", I.

33 Statistisk årsbok för Finland 1908, Helsingfors: Senaatin kirjapaino, 1908, 7.

34 "Uppmaning", I; Ikävalko, T., "Edistysseurat terveysliittoja perustamaan”, Karjalan lehti 9 juni 19I4, I; Harjula, Minna, Tehdaskaupungin takapihat: Ympäristö ja terveys Tampereella 1880-1939, Tammerfors: Tampereen Historiallinen Seura, 2003. 
35 Laitinen, Taawetti, "Suomen kansallista terveysliittoa kehittämään", Vaasa I9 juni 1909, 2; "Kehoitus yhtymään Suomen kansalliseen terveysliittoon", Uusi Suometar 25 juni $1906,3$.

36 Kalela, Jorma, "Yhteiskunnallinen kysymys ja porvarillinen reformismi", Suomalaisen yhteiskunnan politttinen historia, Pernaa, Ville \& Niemi, Mari K. (red.), Helsingfors: Edita, 2005, 3I-44; Haapala et al.

37 Digitala samlingar, Nationalbiblioteket, Tidningar, https://digi.kansalliskirjasto.fi/ search?formats=NEWSPAPER (senast kontrollerad II juni 202I).

38 ReijoWaara, "Liittoon nuoret ja vanhat II", I34.

39 Digitala samlingar, Nationalbiblioteket, Tidskrifter, https://digi.kansalliskirjasto. fi/search?formats=JOURNAL (senast kontrollerad II juni 202I); "Kehoitus kaikille maassamme", Työmies 28 september 1906, 4 .

40 ReijoWaara, Konrad, "Ruotsissa saavuttaa Suomen kansallinen terveysliittoaate tunnustusta", Terveydenhoitolehti, vol. I9, nr II, 1907, I70f.

4I "Suomen kansallisen terveysliiton suhde Suomen Terveydenhoitoyhdistykseen ja niiden tehtävät", Uusi Suometar 9 januari 1907, 2; ReijoWaara, "Kertomus Suomen kansallisen", Duodecim, 405f.; Mustajoki, 321, 323.

42 ReijoWaara, Konrad, "Kertomus Suomen kansallisen terveysliiton väliaikaisen keskustoimikunnan toiminnasta vuosina 1906-1908", Terveydenhoitolehti vol. 20, nr 7-8, 1908, I27; Halmesvirta, "Kansallisen vastustuskyvyn", I3-15.

43 Hans tidigare efternamn var Relander. Hietala, "ReijoWaara, Konrad"; Paikkala, Sirkka, "Snellmanin Ioo-vuotispäivä ja sukunimien suomalaistaminen", Hiidenkivi, vol. I2, nr 3, 2006.

44 ReijoWaara, "Kertomus Suomen kansallisen", Terveydenhoitolehti, I27.

45 "Terveysliitot", Suomalainen 6 februari 1907, 2; "Terveysliittoja perustamaan joka kuntaan", Uudenkaupungin Sanomat 3 december I910, I.

46 ReijoWaara, "Kertomus Suomen kansallisen", Duodecim, 425-44I; Ruotsalainen, "Kertomus Suomen kansallisen", I23-I25.

47 H.S., "Kymin terveysliiton", Terveydenhoitolehti, vol. 28, nr 2, I9I6, 3 I.

48 "Kymin terveysliiton", Etelä-Suomi I februari 1912, 2.

49 ReijoWaara, "Kertomus Suomen kansallisen", Terveydenhoitolehti, I29.

50 ReijoWaara, Konrad, "Mitä voisi", I53-I63.

5I "Otteita terveysliittojen v:kertomuksista v:Ita 1915", Terveydenhoitolehti, vol. 29, nr 3, I916, 45; "Otteita terveysliittojen vuosikertomuksista 1915", Terveydenhoitolehti, vol. 29, nr 3, 1916, 62 .

52 Soikkanen, Hannu, Kunnallinen itsehallinto kansanvallan perustana: Maalaiskuntien itsehallinnon historia, Helsingfors: Maalaiskuntien Liitto, I966; Rasila, Viljo, "Kaupunkien sosiaalipolitiikka ja terveydenhoito I875-1917", Suomen kaupunkilaitoksen historia 2: 1870-luvulta autonomian ajan loppuun, Helsingfors: Suomen Kaupunkiliitto, 1983, 333-374.

53 "Kovin moninaisia harrastuksia", Karjalatar 26 januari I9I I, 3; Harjula, Minna, "Suurlakon tyttäret", Kansa kaikkivaltias: Suurlakko Suomessa I9o5, red. Pertti Haapala et al., Helsingfors: Teos, 2008, I2 I-I36.

54 Alapuro et al.; Sulkunen, Raittius kansalaisuskontona, 98-116; Haapala, Kun yhteiskunta hajosi, 40-46; Männikkö, 59.

55 Sulkunen, Irma, "Naisten voitto", Kansa kaikkivaltias: Suurlakko Suomessa I9o5, Haapala. Pertti et al. (red.), Helsingfors: Teos, 2008, 75-96. 
56 Kalela, 35-44.

57 Salokarpio, "Tyrvännön terveysliitto", Hämeen Sanomat 26 januari 1909, 3; ReijoWaara, "Kertomus Suomen kansallisen", Duodecim, 435-437.

58 "Lähiseuduilta", Eteenpäin 6 juni 1908, 3.

59 Oittinen, Riitta, "Welfare, health and working class women in early 2oth century Finland", The Nordic model of welfare: A historical reappraisal, Christiansen, Niels Finn, Petersen, Klaus, Edling, Nils \& Haave, Per (red.), Köpenhamn: Köpenhamns universitet, 2006, 243-267.

6o Tyyne, "Keuhkotauti ja työläisnaiset", Työläisnainen, vol. 7, nr I6, I913, I25.

61 Mikko, "Mikä on syy?", Työmies I3 februari 1906, 2.

62 J. T., "Valtion velvollisuus varattomia sairaita kohtaan", Pohjois-Suomi I5 mars I907, 3.

63 Oittinen; Toomus Nälänheimo, "Salkusta 228", Sorretun Voima 26 november 1915, 2.

64 Palmberg, A., "Läkaresällskapet och arbetarefrågan", Finska läkaresällskapets handlingar, vol. 65, $\mathrm{nr}$ I2, 1905,678 .

65 Ibid., 68If.

66 Haatanen, Pekka, Suomen maalaisköyhälistö tutkimusten ja kaunokirjallisuuden valossa, Borgå: WSOY, 1968; Juntto, Anneli, Asuntokysymys Suomessa Topeliuksesta tulopolitiikkaan, Helsingfors: Statens tryckericentral, 1990, 59-134.

67 Arppe, N. J., "Työväenkysymys ja terveydenhoito", Terveydenhoitolehti, vol. I9, nr 3, I907, 37-38.

68 Arppe, "Työväenkysymys ja terveydenhoito", 38; Arppe, N.J., "Uudenaikaisia virtauksia terveydenhoidon alalla", Valvoja, vol. 27, $\mathrm{nr}$ 4, 1907, 309-313.

69 Koskimies, Akseli, "Mitä ovat sosiaalihygienia ja sosiaalimedisiina?", Duodecim, vol. 32, $\mathrm{nr} 3$, 1916, I33-147.

70 Halmesvirta, "Kansallisen vastustuskyvyn", 25.

7I ReijoWaara, Konrad, "Oletko repijäin vaiko rakentajien puolella?", Terveydenhoitolehti, vol. I9, nr 6, I907, 89f.; Puks, "Oletko repijäin vaiko rakentajien puolella?", Työmies 4 juli 1907, 7; W, "Kaikki lapset opetettava uimaan", Työmies 9 juli 1907, 3; Halmesvirta, Anssi, Vaivojensa vangit: Kansa kysyi - lääkärit vastasivat, Jyväskylä: Atena, 1998, 35.

72 "Herrain terveyttä hoidetaan", Sosialisti io maj I9II, 3.

73 Toomus Nälänheimo, "Salkusta 228".

74 Halmesvirta, "Kansallisen vastustuskyvyn", 30, 45f., 6o, 63f.; Mustajoki, 368-379.

75 Relander, Konrad, "Piirilääkäreistä ja miten meillä terveyden- ja sairaanhoito maalla on saatava paremmalle kannalle", Duodecim, vol. 4, nr 4, I885, 42-44; Ignatius, I24, I68-I7I, I76f., 521; Mustajoki, I86-I98.

76 ReijoWaara, "Kertomus Suomen kansallisen", Duodecim, 4I5; Relander, Konrad, ”Mitä on oleva päämäärä terveyden ja sairashoidon parantamista tarkoittaville toimenpiteille maassamme”, Duodecim, vol. 6, nr 9, I890, I29-I 40; Harjula, Hoitoonpääsyn hierarkiat, $40-46$.

77 Harjula, Hoitoonpääsyn hierarkiat, 5If.; Mustajoki, 20, 30, 39, 91.

78 ReijoWaara, "Kertomus Suomen kansallisen", Duodecim, 4I5.

79 "Terveysliitot", Suomalainen 6 februari 1907, 2.

8o Harjula, Hoitoonpääsyn hierarkiat, 74, 83, I46.

8I "Uppmaning", I; ReijoWaara, "Kertomus Suomen kansallisen", Duodecim, 4I8-425. 
82 ReijoWaara, "Kertomus Suomen kansallisen”, Duodecim, 435-437; Ruotsalainen, "Kertomus Suomen kansallisen", I24.

83 "Terveysliitto perustettu Alavudelle", Sorretun voima 4 mars I9I4, 2. "Kirje Alavudelta", Pohjalainen 2I april I9I5, 2.

84 Socialdemokraternas partiprogram 17-20.8.1903, https://www.fsd.tuni.fi/pohtiva (senast kontrollerad II juni 202I).

85 Harjula, Minna, "Health citizenship and access to health services: Finland 1900-2000", Social History of Medicine vol. 29, $\mathrm{nr}$ 3, 2016, 573-578.

86 Laitinen, Taavetti, "Yleisen terveyshoidon kohottamiseksi", Terveydenhoitolehti, vol. 3I, nr 4, I9I9, 50; ReijoWaara, Konrad, "Suomen kansallinen Terveysliitto", Terveydenhoitolehti, vol. 30, $\mathrm{nr}$ 9, I918, I29f.

87 Ruotsalainen, Armas, "Terveysliitot lastenhoitoa edistämään!", Terveydenhoitolehti, vol. 30, $\mathrm{nr}$ IO, I918, $\mathrm{I} 58 \mathrm{f}$.

88 Harjula, "Universal, but exclusive", 64 .

89 Ignatius, 628-634, 882f.

90 Ibid., 2I8-220, 633; Halmesvirta, "Kansallisen vastustuskyvyn", 63f.; ReijoWaara, Konrad, "Iltapuhteessa", Terveydenhoitolehti, vol. 30, nr I2, I918, I78f.; Ruotsalainen, Armas, "Neljännen vuosikymmenen alkaessa", Terveydenhoitolehti, vol. 31, nr I, I9I9, If.; "Kehoitus", Duodecim, vol. 43, nr I2, I927, 1020.

9I Männikkö, 5I-79; Koivisto, Hanne, "Nuoren valtion avohaavat", Maamme: Itsenäisen Suomen kulttuurihistoria, Kaartinen, Marjo, Salmi, Hannu \& Tuominen, Marja (red.), Helsingfors: SKS, 13-28; Stenius, Henrik, "Nordic associational life in a European and an Inter-Nordic perspective", Nordic associations in a European perspective, Alapuro, Risto \& Stenius, Henrik (red.), Baden-Baden: Nomos, 2010, 75; Haatanen, Pekka, "Elämän varjopuolelle joutuneiden parissa", Suuriruhtinaskunnasta hyvinvointivaltioon: Sosiaali- ja terveysministeriö 75 vuotta, Haatanen, Pekka \& Suonoja, Kyösti (red.), Helsingfors: VAPK-kustannus, 1992, I35; Korppi-Tommola, Aura, Terve lapsi-kansan huomen: Mannerheimin Lastensuojeluliitto yhteiskunnan rakentajana I920-I99o, Helsingfors: MLL, I990; Bergenheim, Sophy, "Cherishing the health of the people: Finnish non-governmental expert organisations as constructors of public health and the 'people'", Conceptualising public health: Historical and contemporary struggles over key concepts, Kananen, Johannes, Bergenheim, Sophy \& Wessel, Merle (red.), London: Routledge, 2018, IOI-II8.

92 Harjula, Hoitoonpääsyn hierarkiat, I I7-137; Harjula, "Universal, but exclusive", 62-65; Kuusi, Eino, Sosiaalipolitiikka I, Borgå: WSOY, I93 I, 23 f., 270.

93 Larsson, Sigrid, "Keskitetty terveyssisartoiminta", Maalaiskunta, vol. I7, nr 9, I938, I77.

94 Laurent, Helene, Asiantuntijuus, väestöpolitiikka, sota: Lastenneuvoloiden kehittyminen osaksi kunnallista perusterveydenhuoltoa I904-I955. Statsvetenskapliga fakultetens publikationer vol. 6I, Helsingfors: Helsingfors universitet, 2017, 254, $264 \mathrm{f}$.

95 Harjula, "Universal, but exclusive", 65-67; Harjula, Hoitoonpääsyn hierarkiat, I 17-I23, I38-23I.

96 Laurent, 235 . 